Nunt. Antiquus, Belo Horizonte, v. 15, n. 2, p. 27-48, 2019

\title{
Do rito ao palco: inversão de gênero e performance nas Tesmoforiantes, de Aristófanes
}

\section{From Rite to Stage: Gender Inversion and Performance in Aristophanes' Thesmophoriazousae}

\author{
Edilane Vitório Cardoso \\ Universidade Federal do Ceará (UFC), Fortaleza, Ceará / Brasil \\ edilaneathe@gmail.com
}

Resumo: Das onze comédias remanescentes de Aristófanes, três utilizam a inversão de papéis de gênero em que as mulheres são representadas exercendo funções convencionalmente desempenhadas por homens. Lisistrata (411 a.C.) e Assembleia de mulheres (392 a.C.) tratam da intrusão da figura feminina nos espaços públicos de Atenas - Acrópole e Ágora respectivamente, prefigurando a participação delas na vida política e econômica da cidade. Em Tesmoforiantes (411 a.C.), entretanto, temos o reposicionamento em torno da batalha dos sexos e do travestismo de gênero, o que compreende o domínio da estética e do visual, que se projeta no próprio teatro. Em vez do confronto coletivo de homens e mulheres, a peça dirige as ações das mulheres contra um único alvo masculino - o poeta trágico Eurípides. Salvas do constrangimento social e dos padrões convencionais que as mantêm dentro do ô̂kos, silenciosas e inertes em espaços públicos do discurso e da ação, no palco da comédia as mulheres são representadas como protagonistas de seus atos e manifestos. Nesse sentido, o estudo que ora apresentamos busca analisar a inversão de papéis de gênero, travestismo e performance na comédia Tesmoforiantes. A proposta parte da análise do reajuste das posturas performáticas que identificam as mulheres no ritual das Tesmofórias, concentrando o estudo nas questões que giram em torno da inversão de papéis e travestismo de gênero no palco. Assim, com vistas ao debate pretendido, nos ancoramos teoricamente nos estudos de Zeitlin (1981), Tzanetou (2002), Vernant (1989), Silva (1979-1980) e McClure (1999).

Palavras-chave: Aristófanes; Tesmoforiantes; gênero; ritual. 


\begin{abstract}
The reversal of gender's roles is staged in three of the eleven remaining comedies by Aristophanes. By "reversal of gender's roles" we mean that women are represented performing functions conventionally performed by men in these plays. Thus, both the Lysistrata (411 BC) and the The Assemblywomen (392 BC) deal with the intrusion of the female figure in the public spaces of Athens -the Acropolis and the Agora, respectively -by prefiguring their participation in both the political and the economic life of the city. In the Thesmophoriazousae (411 BC), however, there is a repositioning concerning a battle of sexes and gender transvestitism, which encompasses the domain of aesthetics and visual, and this is projected in the theater itself. Instead of a collective confrontation between men and women, the play directs women's actions against a single male target: the tragic poet Euripides. Saved from the social embarrassment and conventional patterns that keep them within the oikos, silent and inert in public spaces of speech and action, on the stage of comedy women are represented as protagonists of their acts and manifestos. For this reason, the present study aims at analyzing the inversion of gender roles, transvestitism, and performance in the comedy Thesmophoriazousae. This study starts with the analysis of the readjustment of the performative postures which identify women in the Festival of the Thesmophoria, by focusing its argumentation in questions that revolve around the reversal role and gender transvestitism on the stage. Thus, in order to develop such discussion, this work is theoretically grounded on the studies of Zeitlin (1981), Tzanetou (2002), Vernant (1989), Silva (2015), and McClure (1999).
\end{abstract}

Keywords: Aristophanes; Thesmophoriazousae; gender; rite.

\title{
Introdução
}

Conceber gênero como categoria de análise nos posiciona no centro de reflexões sobre os papéis, normas, atitudes e comportamentos socialmente construídos e atribuídos a homens e mulheres em qualquer sociedade. Na Atenas do século V a.C., a posição social e política dos homens e das mulheres prescreveu a participação destes na guerra e na política - isto é, no seu engajamento no espaço público - enquanto as mulheres viviam uma existência mais marginal, definida por suas obrigações para com os parentes, como esposas e mães, como comenta Tzanetou (2002, p. 20). Desse modo, é relevante salientar que a condição da mulher da Atenas desse período não se apresenta uniforme, já que se deve considerar a classe social na qual ela estava inserida, bem como questões culturais que se projetam sobre as delimitações dos papéis 
e funções impostos ao feminino. Nesse sentido, em linhas gerais, era permitida a participação feminina em casamentos, ritos fúnebres e festivais religiosos sancionados pelas leis da cidade, de modo que nesses espaços pré-determinados cabia às mulheres a condução da vida religiosa da pólis, em nome do bem-estar da comunidade e, em certa medida, havia a atenuação de sua exclusão das esferas públicas e da política da cidade.

Os padrões de conduta feminino e masculino também eram marcadamente distintos e delimitados. Segundo Tzanetou (2002, p. 328), na ideologia democrática ateniense, coragem, bravura e envolvimento cívico foram valorizados, acima de tudo, como atributos masculinos coletiva e individualmente -, ao passo que silêncio, isolamento, recato e modéstia eram qualidades e valores atribuídos ao feminino. As três peças de Aristófanes em que personagens femininas figuram como protagonistas apresentam uma variação e subversão quando se trata dos padrões normativos das relações de gênero. As principais abordagens para a representação do gênero feminino no drama grego explicaram sua importância para compreender os modelos de masculinidade e feminilidade. Nesse sentido, compreendemos que o teatro como instituição cívica serviu para educar os cidadãos do sexo masculino e que, ao representar as mulheres como o outro - na dimensão do estranho, desconhecido -, as peças interpretam o feminino de maneira antitética em relação ao masculino.

Aristófanes trata da inversão de papéis de gênero em três peças de sua autoria. Em Lisístrata (411 a.C.) e Assembleia de mulheres (392 a.C.) temos como abordagem a intrusão da figura feminina nos espaços públicos de Atenas - Acrópole e Ágora respectivamente, prefigurando a participação das mulheres na vida política e econômica da cidade. Em Tesmoforiantes (411 a.C.), contudo, nos deparamos com o reposicionamento em torno da batalha dos sexos e do travestismo de gênero, o que compreende o domínio da estética e do visual, aspectos que se projetam no próprio domínio do teatro e dos recursos próprios da encenação. Nesse sentido, o estudo que se segue pretende analisar sob o prisma da inversão de papéis de gênero, travestismo e performance, a comédia Tesmoforiantes, representada em 411 a.C. 
A proposta parte da observação do reajuste das posturas performáticas que identificam as mulheres no ritual das Tesmofórias, concentrando o estudo nas questões que giram em torno da inversão de papéis e travestismo de gênero no palco. Em face disso, a peça satiriza a experiência ritual das mulheres e não respeitosamente retrata as Tesmofórias como um festival muito importante, celebrado em toda a Grécia, que promovia a agricultura e fertilidade humana. E, no entanto, apesar da invasão do personagem Parente e sua zombaria das mulheres, o papel das mulheres no ritual não é realmente enfraquecido nesta peça. As personagens femininas que habitam o palco cômico e protestam contra seu retrato no drama não pretendem redefinir seus papéis sociais como esposas e mães. Em vez disso, elas usam a autoridade de seus papéis para montar um ataque bem-sucedido contra Eurípides porque ele enfraquece essas funções.

Expostas as considerações iniciais, assinalamos que a discussão pretendida tem por base um estudo de caráter bibliográfico. Dessa forma, para a viabilização e suscitação do debate proposto nos amparamos nas discussões teóricas de Zeitlin (1981), Tzanetou (2002), Vernant (1989), Silva (1979-1980) e McClure (1999). No que diz respeito à abordagem da análise a ser empreendida, o estudo se configura em duas seções cuja organização obedece à seguinte divisão: 1) Política dos espaços e das vozes: gênero e sociedade no drama grego, seção na qual discutiremos questões relativas às normas e condutas masculinas e femininas na ideologia democrática ateniense e sua projeção no teatro; 2) Do rito ao palco: inversão de gênero e performance nas Tesmoforiantes, seção em que efetuaremos a análise central proposta com vistas a discutirmos ritual, inversão de papéis, travestismo e performance na comédia aristofânica selecionada.

\section{Política dos espaços e das vozes: gênero e sociedade no drama grego}

Ao considerarmos uma cultura em que se legislava um alto grau de dimorfismo sexual na divisão social do trabalho - um dimorfismo que também servia para dividir o masculino do feminino como encabeçando a lista de oposições binárias no mapa do mundo, tanto acima como 
abaixo, tanto no interior como no exterior -, na Grécia do século V, os parâmetros dessas divisões e as associações simbólicas mais amplas que se seguiram não se tratavam apenas de uma simples oposição entre macho e fêmea, cada categoria inserida em esferas separadas de interesse, mas sim da noção de uma diferença muito mais profunda e demarcadora, até inerradicável, entre os sexos, como se pertencessem a espécies diferentes.

Apareceu uma "raça de mulheres", segundo nos relata Hesíodo em Os trabalhos e os dias (47-105, para o conjunto da história). Pandora foi o primeiro exemplar dessa raça, uma vez que ela foi criada por Zeus em punição aos homens pelo roubo do fogo praticado pelo titã Prometeu. O mito de Pandora é uma variante do tema bem conhecido nos mitos de origens em todo o mundo. Pandora é concebida por Zeus e forjada por Hefesto, o deus metalúrgico, em parceria com outros deuses que a moldam com características específicas. Sendo criada pela suprema divindade masculina, a entrada da mulher em cena é apenas o começo da história. Isso fornece a ocasião para uma narrativa etiológica que conta como através de sua agência, o mundo foi transformado em seu estado atual. Seu status secundário funciona como um significante da diferença e perturbação que provoca a chamada "condição humana", já que é Pandora quem introduz a morte, a desgraça e o mal no mundo, juntamente com a laboriosa labuta da existência humana. Hesíodo narra o mito de Pandora em duas versões, a primeira em seu poema épico cosmogônico Teogonia (570-612) e a segunda em Os trabalhos e os dias (57-104), obra esta vinculada ao gênero didático de literatura de sabedoria, como apontam alguns críticos. Os detalhes diferem, mas, em cada caso, a mulher criada figura como o resultado de um jogo de raciocínio entre o titã Prometeu e Zeus, que se revolta com uma série de decepções e enganos em conexão com a troca de presentes.

$\mathrm{O}$ estudo de gênero em um contexto social requer que alcancemos, além do primeiro nível de análise na identificação de figuras representativas, estruturas e formas de ação ou caracterização específicas para cada sexo. Todas essas considerações também envolvem ideias sobre a própria sexualidade, na forma masculina ou feminina, o corpo e suas partes: como constituído e como imaginado em termos corpóreos ou não 
corpóreos. Além disso, o gênero e a sexualidade operam tanto no nível literal de referência nas relações familiares quanto no metafórico entre os espaços masculino e feminino, entre a casa e a cidade - ổkos e pólis. Especulações sobre parentesco ou estratégias reprodutivas afetam não apenas a organização social, mas também o corpo político e seus modos de autodefinição em relação à terra que a pólis ocupa, o status de seus vários habitantes e os laços que os ligam ou dividem.

Nesse sentido, em conformidade com a ideologia democrática ateniense, as mulheres gregas eram, em geral, despossuídas de direitos políticos ou jurídicos e encontravam-se inteiramente submetidas socialmente. A ateniense casada e de classe social abastada vivia a maior parte do tempo confinada às paredes de sua casa, detendo no máximo o papel de organizadora das funções domésticas, estando, portanto, submissa a um regime de quase reclusão. Mesmo antes do casamento, era impensável a possibilidade de uma jovem encontrar-se livremente com rapazes, visto que vivia fechada nos aposentos destinados às mulheres - 0 gineceu. Deviam neste espaço permanecer para ficar longe dos olhares externos, separadas até dos membros masculinos da própria família.

Vernant (2002, p. 53), em As origens do pensamento grego, observa que o que implicava o sistema da pólis era o proeminente exercício dado à palavra, como manifestação de status, poder e autoridade. Palavra ou discurso, que se refere ao debate, argumentação. Assim, nas palavras de Vernant (2002, p. 54),

o que implica o sistema da pólis é primeiramente uma extraordinária preeminência da palavra sobre todos os outros instrumentos do poder. Torna-se o instrumento político por natureza, a chave de toda autoridade no Estado, o meio de comando e de domínio sobre outrem. Esse poder da palavra de que os gregos farão uma divindade: Peithó, a força da persuasão - lembra a eficácia das palavras e das fórmulas em certos rituais religiosos ou o valor atribuído aos ditos do rei quando pronuncia soberanamente a thémis. Entretanto, a palavra não é mais o termo ritual, a fórmula justa, mas o debate contraditório, a discussão, a argumentação. 
Nesse sentido, o silêncio imposto socialmente ao sexo feminino significava sua total exclusão da esfera política da cidade. Ademais, os escassos conhecimentos adquiridos pela mulher ao longo de sua vida provinham, quando era possível, do contato com o pai e com os homens da casa. Em contrapartida, o homem, sendo constantemente solicitado na vida política e social da cidade, encontrava-se totalmente indiferente às questões domésticas confiadas à esposa. Percebemos, logo, que o espaço público, neste contexto, e tudo que lhe diz respeito, tem vinculação com o sexo masculino, ao passo que os limites do ambiente doméstico configuram-se como um território associado ao gênero feminino. Tratam-se, portanto, de espaços sociais demarcados a partir do gênero dos indivíduos.

De acordo com McClure (1999, p. 23), ao sancionarem as apresentações em público, através do recurso das personagens, de gêneros típicos de fala feminina (lamento, oração, casamento, discurso obsceno ritual) ou por meio de intervenções que estão dentro do alcance de seus deveres ritualísticos, as peças gregas exploram a dialética entre as identidades reais e simbólicas das mulheres, colocando personagens femininas no centro da negociação de problemas que afetam a comunidade de cidadãos. Os dramaturgos gregos adaptaram suas tramas a partir do repertório mitológico sobre as famílias reais das cidades de Tebas, Argos, Troia e, em certa medida, Atenas. Assim, os protagonistas masculinos e femininos nas tragédias, por exemplo, são oriundos da classe aristocrática que governa a cidade e, em virtude de sua origem, estes personagens masculinos e femininos têm maior liberdade de atuação no palco, ou seja, não estão estritamente vinculados às instituições da sociedade ateniense contemporânea, como comentam Vernant e Vidal-Naquet (1990, p. 43).

Dessa forma, o anacronismo, a criação de analogias específicas entre passado e presente, permitiu ao público democrático ateniense relacionar os dilemas e lutas dos personagens heroicos com suas próprias experiências. A entrada de personagens femininas no palco inverteu a divisão de gênero do espaço, que marcou a família como feminina e a cidade como espaço masculino. Esta convenção enfatizou a continuidade em vez das divisões entre a ação masculina e a feminina. 
McClure (1999, p. 23) comenta que o antagonismo do gênero se evidencia a partir de disputas que afetam as famílias em que as mulheres estão presentes. Ademais, em peças que lidam com problemas decorrentes da família, ou provenientes do seio familiar, as crises irrompem quando um personagem masculino age contra os interesses de sua família. Em vista disso, a personagem feminina retalia exigindo vingança e incorporando o furor vingativo, ou seja: assumindo "comportamentos masculinos" em sua ação. Assim, temos no Agamêmnon, de Ésquilo, o exemplo de Clitemnestra, que é retratada exercendo o poder como um homem e governando Argos na ausência do marido, além de ser a responsável por tramar a vingança contra ele - por causa do sacrifício da filha Ifigênia -, ao lado do amante Egisto. Na peça, a inclinação de Clitemnestra pelo poder diminui a masculinidade de Egisto, o qual muitas vezes é referido na peça como leão covarde, ao passo que Clitemnestra é aludida como mulher de ânimo viril. Orestes, o filho, configura o modelo desviante de postura feminizada. Para vingar a morte do pai, o jovem assassina a mãe e o amante, e a seguir, sendo absolvido no tribunal dos deuses, reestabelece a ordem patriarcal da cidade.

Para McClure (1999, p. 24), o investimento da tragédia em uma tipologia complexa de personagens femininas é um veículo para explorar a identidade masculina, já que apresenta a mulher como o oposto e agindo a partir de uma posição marginal ou subordinada, mas com questões de autodeterminação moral que levam a uma reavaliação dos ideais de heroísmo e masculinidade. Assim, segundo a autora, o diálogo entre o passado heroico do mito e o presente democrático produz disjunções semelhantes nos encontros entre personagens masculinos, na medida em que alguns personagens atendem aos objetivos da ideologia cívica ateniense. Em muitas peças trágicas assistimos ao confronto entre valores épicos e dever cívico que sugere que o heroísmo masculino não é mais compatível com a visão cívica da pólis grega.

O quadro social em que as comédias de Aristófanes são representadas, no século $\mathrm{V}$ a.C., ainda segue em grande parte um modelo bastante tradicional. Ainda que estejamos no período democrático de Atenas, o órgão central do poder político, a assembleia, não permitia a 
presença feminina em seus domínios. Assim, somente em festivais de caráter religioso as mulheres poderiam exprimir-se sem vigilância ou censuras. Em Lisistrata, uma passagem sobre essa vinculação da mulher, desde a infância, aos ritos religiosos ilustra o que afirmamos:

Desde os sete anos que sou arréfora. Aos dez, fazia eu bolos sagrados para a nossa padroeira. Mais tarde, na minha túnica açafrão, fui ursa nos Braurônios. E enfim, depois que me tornei numa bela mocetona, fui canéfora, com o meu colar de figos secos. (Lisistrata, 641-647).

O excerto acima faz parte da fala do coro da peça e por ele podemos observar a ordem das funções religiosas destinadas às mulheres desde a infância. Há uma espécie de catalogação das funções e missões do sexo feminino na execução dos ritos. Segundo Maria de Fátima Silva, os festejos religiosos eram espaços de convívio social para as atenienses, um dos raros momentos em que era possível às mulheres serem vistas em público e terem um breve contato com seus concidadãos. Desse modo, segundo Silva:

Festivais havia que lhes competiam exclusivamente, como as Tesmofórias e as Esciras, cenários escolhidos por Aristófanes para exibir a astúcia feminina, livre da vigilância dos homens, com a licenciosidade habitual na comédia antiga. $\mathrm{O}$ caráter misterioso destes rituais cobre a maquinação de duas importantes conspirações, contra Eurípides, no caso das Tesmoforiantes, contra os homens que tem se mostrado maus administradores da cidade em $A$ assembleia das mulheres. (SILVA, 1979-1980, p. 99).

Além dos festivais religiosos, a participação feminina também era registrada em cerimônias menores, como as Dionísias rurais, e as de caráter privado, como os casamentos e os ritos fúnebres. Contudo, de um modo geral, o cotidiano da mulher ateniense desenrolava-se no ambiente privado do espaço doméstico. Os contatos mais estreitos ocorriam com a mãe e com as escravas da casa. Assim, eram mulheres reclusas nos ambientes destinados ao seu sexo, distanciadas até do convívio das figuras 
masculinas da família, e, mesmo que com esses tivessem contato, era recomendado a elas recato e silêncio.

Sendo criada no isolamento e na subserviência, a jovem ateniense era preparada para sua futura condição de esposa dócil, de quem o marido esperava uma administração equilibrada do patrimônio e a habilidade de uma dona de casa, nada além disso. Desse modo, as expectativas e os anseios culturais desta jovem ateniense não eram sequer cogitados e sim completamente desconsiderados, salvo raras exceções. Segundo Silva (1979-1980, p. 41), a maior parte das mulheres cultas era formada por aquelas que não eram reconhecidas como cidadãs. Silva comenta ainda que o exemplo mais comum é o de Aspásia de Mileto, ${ }^{1}$ a companheira de Péricles, notadamente reconhecida por sua inteligência e perspicácia política.

Silva (1979-1980, p. 45) comenta também que a situação de mulheres provenientes de classe menos abastada era um pouco diferente. A mulher plebeia tinha uma realidade de contingência material, em que deveria assegurar com seu próprio sustento a casa e os filhos. Esta mulher vivia um pouco mais fora do espaço doméstico - portanto menos presa ao ô̂kos -, ocupada nos trabalhos do campo ou sendo proprietária de um pequeno negócio, por exemplo, uma banquinha no mercado, como é o exemplo da segunda mulher nas Tesmoforiantes, viúva e mãe de cinco filhos, que na peça é uma vendedora de flores.

\section{Do rito ao palco: inversão de gênero e performance nas Tesmoforiantes}

Segundo Tzanetou (2002, p. 333), o ritual das Tesmofórias faz alusão ao luto de Deméter pelo rapto de sua filha Perséfone. O mito é contado no Hino homérico a Deméter e também era conhecido

\footnotetext{
${ }^{1}$ É citada na Suda, enciclopédia bizantina do século X, por suas habilidades e inteligência retórica. Ao lado de Diotima de Mantinea, foi referida por Sócrates como uma das mais importantes personalidades a orientá-lo em seu desenvolvimento intelectual e filosófico. Era uma mulher bastante influente no círculo filosófico e político de Atenas, promovia reuniões em sua casa e participava de debates políticos da época.
} 
pelo público ateniense através dos Mistérios de Elêusis. Informações específicas sobre os três dias do ritual nos são explicitadas pela autora:

O primeiro dia é chamado Anodos (Subida), as mulheres neste dia sobem ao Tesmofórion e fazem preparativos para o festival. Duas mulheres, que foram eleitas como magistrados oficiais, presidem ao festival como oficiais. As mulheres montam tendas improvisadas nas quais passam as duas noites seguintes longe de suas casas, uma experiência única na vida religiosa das mulheres. No segundo dia, Nesteia (Jejum), as mulheres imitam o luto de Deméter, sentando no chão em assentos feitos de plantas anafrodisíacas, em jejum; elas também praticavam a obscenidade ritual. Todos estes elementos são encontrados em contextos de fertilidade e ritos fúnebres. No terceiro dia, Kalligeneia, as mulheres oferecem sacrifícios, festejam e celebram o retorno de Perséfone como uma renovação simbólica de sua própria fertilidade. O último dia comemora o papel de Deméter como promotora da fertilidade humana e agrícola. (TZANETOU, 2002, p. 332-333, tradução nossa).

A presença de plantas anafrodisíacas, ainda conforme Tzanetou (2002, p. 334), simbolizava a castidade das mulheres durante o festival, já que elas reverenciavam simbolicamente seu status anterior de virgens, enquanto a obscenidade ritual estava associada à promoção da fertilidade. Nesse sentido, a peça Tesmoforiantes ou As mulheres que celebram as Tesmofórias trata do rito realizado por mulheres atenienses casadas em honra às deusas ctônias Deméter e Perséfone. Nesta comédia, o coro é formado pelas mulheres que estão celebrando as Tesmofórias e os principais embates travados são entre o coro e o Parente, personagem que se transveste de mulher.

Logo no início da reunião das mulheres no Tesmofórion, percebemos a atuação feminina muito próxima à dos homens nos tribunais e assembleias. A fala das mulheres é permeada de termos convencionalmente relacionados ao universo político masculino. Desse modo, observamos como elas tratam da reunião como assembleia, se autoproclamam conselho/povo das mulheres, comparam-se a oradores 
e fazem um discurso longo e delineado retoricamente. Nesse sentido, mesmo o festival das Tesmofórias sendo mais marcadamente religioso do que político, percebemos que Aristófanes representa a celebração do festival também com fortes relações ao espaço democrático ateniense. Os fragmentos a seguir reforçam o que afirmamos:

MULHER: Orai aos deuses olímpicos e às olímpicas, aos píticos e às píticas, aos délios e às délias, e a todos os outros deuses. Se alguém conspirar algum mal ao povo das Mulheres, ou enviar arautos a Eurípides e aos Medas sobre algum prejuízo ao povo das Mulheres, ou planejar ser tirano, ou ajudar a repor o tirano, ou denunciar uma Mulher com um filho postiço, ou uma serva seduzindo a patroa vá cochichar no ouvido do patrão, ou encarregada de uma mensagem portar mentiras e não dê jamais o que prometeu, ou uma Mulher velha dê presentes a um amante, ou a cortesã receba e vá trair o amigo, e se o taberneiro ou taberneira enganar na medida legal do côngio e do cótilo, rogai para que pereça de modo terrível este e sua família, suplicai para vós outras que os deuses vos deem todas as coisas boas. (Tesmoforiantes, 330-351, grifos nossos).

MULHER: Escutai todas. Isto decidiu o conselho das mulheres: Timocleia sendo presidente, Lisila, a secretária e Sóstrata, a oradora: fazer uma assembleia na manhã do dia do meio das Tesmofórias, quando nós temos mais folga, e deliberar primeiro sobre Eurípides, o que ele deve sofrer; pois que comete injustiça, todas concordamos. Quem quer se pronunciar? (Tesmoforiantes, 373-381, grifos nossos).

A celebração das Tesmofórias era uma das únicas oportunidades permitidas às mulheres para escapar da rotina de reclusão do oîkos e da vigilância masculina. Conforme o argumento da peça, Eurípides é acusado pelos principais desentendimentos domésticos ao revelar os "vícios femininos" em suas tragédias. Nesse sentido, o tragediógrafo seria o responsável por tornar públicos os hábitos privados das mulheres, fato que passaria a comprometer o relacionamento entre maridos e esposas, pais e filhas. A atitude das mulheres, assim, é a de reagir durante 
a celebração das Tesmofórias, constituindo um tribunal em que os discursos são carregados de elementos persuasivos, no plano da retórica, e condenando à morte Eurípides:

PRIMEIRA MULHER: Não foi por ambição minha, pelas duas deusas, que me levantei para falar, ó Mulheres; pobre de mim, há muito tempo suporto forçosamente ver que somos ultrajadas por Eurípides, filho da vendedora de legumes e ouvir muitas maldades e de toda espécie. Pois, de qual injúria ele não nos cobre? E quando não nos calunia, por poucos que sejam os espectadores, os atores e coros, as levianas, as apaixonadas por homens nos chama, as bebedoras de vinho, as traidoras, as tagarelas, as sem valor, a grande desgraça dos maridos? (Tesmoforiantes, 382-394, grifos nossos).

Em face disso, a peça satiriza a experiência ritual das mulheres e retrata as Tesmofórias como um festival muito importante celebrado em toda a Grécia, que promovia a agricultura e fertilidade humana. E, no entanto, apesar da invasão do Parente e sua zombaria das mulheres, o papel das mulheres no ritual não é realmente enfraquecido nesta peça. As personagens femininas que habitam o palco cômico e protestam contra seu retrato no drama não pretendem redefinir seus papéis sociais como esposas e mães. Em vez disso, elas usam a autoridade de seus papéis para montar um ataque bem-sucedido contra Eurípides porque ele enfraquece essas funções.

O poeta trágico Agatão é o primeiro a ser procurado por Eurípides, sobretudo em virtude de seu aspecto físico, já que não usa barba, possui "traços delicados", voz doce, e, ademais, por também compartilhar do mesmo ofício de Eurípides. Todos esses elementos contribuiriam para o sucesso do seu disfarce em mulher, bem como para a defesa da reputação de Eurípides no tribunal das mulheres. Após a recusa de Agatão, o personagem Mnesíloco ou Parente é quem se traveste de mulher para participar do ritual das Tesmofórias com vistas a defender Eurípides diante das acusações das mulheres. 
A comédia Tesmoforiantes, conforme explicitamos, reposiciona a batalha dos sexos no domínio visual e, mais precisamente, no domínio dos artifícios e recursos que são próprios do teatro. Assim como a peça mais conhecida de Aristófanes, Lisistrata, também representada em 411 a.C., a comédia Tesmoforiantes está situada na Acrópole. Este espaço, segundo as normas estabelecidas, não é apropriado para as mulheres, mas a elas é concedido de acordo com as regras de seu festival anual, que reserva o ambiente sagrado para seu uso exclusivo nos rituais de fertilidade dedicados a Deméter e Perséfone. Em Lisistrata, as mulheres, privadas da companhia sexual de seus maridos devido à ausência destes por ocasião do conflito bélico entre Atenas e Esparta, a guerra do Peloponeso (431404 a.C.), encenam uma abstinência sexual contra eles, reivindicando a paz entre as cidades e o regresso dos maridos aos seus lares. Conforme o enredo da comédia, a cidade está praticamente vazia, já que os homens, sobretudo os jovens, estão guerreando, e este é o principal motivo pelo qual as esposas decretam greve.

Considerando o nível dramático, a peça constrói-se em duas partes em torno das quais se delineiam os planos concebidos e arquitetados pela protagonista Lisístrata. O primeiro plano é a tomada da Acrópole pelas mulheres mais velhas; já o segundo diz respeito à proposta de greve de sexo à qual todas as esposas jovens da Grécia devem aderir. Tal plano de greve é o primeiro a ser apresentado no prólogo da comédia, porém não foi posto em cena explicitamente, é apenas aludido, e segue-se ao plano de ocupação da Acrópole. As passagens destacadas da peça abaixo, a título de ilustração, referem-se ao momento em que Lisístrata, após a convocação das mulheres, fala sobre a greve e a ocupação da Acrópole pelas mulheres mais velhas:

Li. Direi, pois não é preciso que o assunto fique oculto.

É que para nós, ó mulheres, se estamos dispostas a obrigar os homens a fazerem a paz, é preciso abandonar...

Ve. O que? Fala.

Li. Fareis então?

Ve. Faremos, mesmo que nós tenhamos que morrer. 
Li. É preciso então que abandonemos o pênis.

Por que vos inquietais? Para onde ides?

Vós, por que fazeis beicinho e negais?

Por que a cor muda? Por que uma lágrima corre?

Fareis ou não fareis? Ou o que vós pretendeis?

Li. Mas isto também está bem preparado.

Pois ocuparemos a Acrópole hoje.

É que às mulheres mais velhas foi ordenado fazerem assim, enquanto combinamos estas coisas, fingindo sacrificar, tomarem a Acrópole. (Lisistrata, 122-136).

Em Assembleia de mulheres, peça representada em 392 a.C., a personagem principal convence as mulheres a irem à assembleia disfarçadas de homens com vistas a propor um governo delas para a cidade, com a modificação das leis e sendo elas próprias as novas legisladoras. As protagonistas Praxágora e Lisístrata são figuras femininas marcantes que atuam, cada uma a seu modo e conforme suas necessidades, em prol de um ideal coletivo. Após o discurso de Praxágora, delineado com artifícios retóricos, fica estabelecido, então, que a cidade será governada pelas mulheres. A nova proposta de legislação, tendo Praxágora como autora e porta-voz, é a de que todos os cidadãos devam entregar seus bens ao governo, formando uma espécie de fundo comum. Por causa da atuação e do discurso desta, há a aprovação de algo nunca antes considerado para a salvação de Atenas, um governo administrado pelas mulheres. Trata-se de uma comédia que também traz o cômico a partir de algo considerado utópico para a época, uma inversão total de papéis e uma transgressão dos espaços.

Em se tratando do objeto deste estudo, a peça Tesmoforiantes, conforme Tzanetou (2002, p. 46), é uma peça complexa e integrada. Está localizada na intersecção de várias relações: entre homem e mulher; entre tragédia e comédia; entre teatro (tragédia e comédia) e festival (ritual e mito); entre festival (Tesmofórias) e festival (o dionisíaco, que fornece a ocasião para sua performance e que determina sua essência cômica); e, finalmente, entre formas delimitadas (mito, ritual e drama) e as "realidades" mais fluidas da vida cotidiana. Nesta comédia, essas relações 
são instáveis e reversíveis: atravessam fronteiras e invadem os territórios uns dos outros; elas apagam e restabelecem distâncias hierárquicas para refletir ironicamente umas sobre as outras e sobre si mesmas.

O cenário da peça e o progresso da trama são construídos não apenas para aproveitar ao máximo o valor cômico da representação da figura feminina, mas também para usar as inversões de gênero e chamar atenção para a problemática da imitação e representação que conectam o travestismo, o disfarce, e a ilusão com a paródia mimética de textos. $\mathrm{O}$ travestismo trabalha no nível visual; a paródia das tragédias, no nível verbal. Juntos esses recursos expõem as fronteiras do cruzamento de gêneros e de genitores; juntos eles exemplificam a equivalência de intertextualidade e intersexualidade, como comenta Tzanetou. $\mathrm{O}$ efeito de tornar um poeta trágico o protagonista cômico em uma trama cômica e de elevar a paródia ao discurso dominante da peça transfere a disputa entre os sexos para outro nível, que não apenas reflete as tensões entre os papéis sociais de homens e mulheres, mas também se concentra em sua representação teatral como personagens trágicas e cômicas.

A parábase exemplifica fortemente as mulheres nesta peça reivindicando uma participação nas fortunas da cidade. Nela (785-845), as mulheres elogiam a "raça feminina" (786) e refutam as críticas dos homens às mulheres como "o mal" em sua casa (785-799) ao elogiar as mulheres de Atenas por suas contribuições cívicas (799-845). Apesar de suas paródias, a parábase traz vários pontos válidos. Na privacidade do recinto que identifica o ritual das Tesmofórias, as mulheres decidem vingar-se do poeta trágico Eurípides, a quem acusam de misoginia e de calúnia no retrato dramático das mulheres. Foi ele o responsável por tornar suas vidas intoleráveis, segundo elas. Seus maridos chegam em casa vindos do teatro, todos com suspeita em cada gesto e movimento, e as trancam em casa. O próprio Eurípides aparece na abertura da peça para inventar sua contraproposta e resgatar-se do perigo iminente que determinará, neste dia, se ele viverá ou morrerá. Assim, ele deve finalmente enviar seu próprio Parente. Vestido como uma mulher com trajes e acessórios fornecidos por Agatão, barbeado e depilado no palco, o Parente Mnesíloco se dirige à Acrópole para se misturar às outras 
mulheres e cumprir os planos da conspiração. A seguir, fragmentos da peça que se referem ao início do momento em que Parente é disfarçado de mulher:

PARENTE: Eis aí ao chão. O que pretendes fazer-me, então? EURÍPIDES: Raspar isto e queimar-te por baixo.

PARENTE: Faz então, se assim te agrada, ou eu não deveria ter me oferecido.

EURÍPIDES: Agatão, tu deves portar sempre uma navalha, empresta-nos uma agora.

AGATÃ O: Pega-a tu mesmo dentro do estojo.

EURÍPIDES: Tu és gentil. Senta-te e enche a face direita.

PARENTE: Ai de mim! (Tesmoforiantes, 211-223).

Contudo, o Parente é desmascarado e seu verdadeiro sexo é revelado tanto pela natureza de sua defesa em nome de Eurípides quanto pela informação de Clístenes - outro personagem com traços afeminados e reconhecido como um político amigo das mulheres -, que consegue inserir-se no ritual e avisá-las do intruso disfarçado. Enquanto Clístenes sai para trazer de volta o arqueiro cita para expulsar o impostor, o Parente é quem recorre a elaboradas paródias do drama euripideano. Ele tenta um papel trágico após o outro em seus esforços para salvar-se, finalmente trazendo Eurípides ao palco, não uma, mas duas vezes, para imitar aqueles de seus próprios personagens que poderiam resgatar o Parente. Quando esse recurso fracassa, Eurípides, por fim, se reconcilia com as mulheres e, vestido agora como uma velha alcoviteira, consegue desviar o arqueiro cita com um ardil cômico, não trágico - a entrada da jovem dançarina -, para que ele e o Parente possam fugir:

EURÍPIDES (como velha): A moça vai ensaiar, ó arqueiro, pois ela deve dançar para alguns homens.

ARQUEIRO: Dançar, ensaiar eu não impedir. Como é lebe, como uma pulga no véu. 
EURÍPIDES: Vamos retira este manto, ó filha, e sentando-te nos joelhos do cita estende os pés, para eu descalçá-los.

ARQUEIRO: Sim, sim. Senta, senta sim, sim, bilhinha. Que duro a teta como um rábano.

EURÍPIDES: Tu, toca rápido; ainda temes o cita?

ARQUEIRO: Belo bunda. Tu chorar, se não ficar aí dentro. Bem, a aparência é bela em torno da barra.

EURÍPIDES: Está bom. Tome o manto; já é hora de nos pôr a caminho.

ARQUEIRO: Não me peijará antes?

EURÍPIDES: Perfeitamente; beija-o.

ARQUEIRO: ó, ó, ó papapapai, que língua doce, como mel ático. (Tesmoforiantes, 1175-1196).

Segundo Tzanetou (2002, p. 335), o dispositivo de encenar a presença das mulheres na Acrópole tem uma vantagem dupla. Em um nível, a ocupação feminina do espaço cívico mantém a transgressão que a presença delas no palco público implica. Por outro lado, os regulamentos rituais que colocam as mulheres no comando oferecem ricas possibilidades cômicas para o uso indevido da linguagem masculina em sua imitação daquilo que seria típico das instituições masculinas do tribunal e da assembleia. Além disso, o artifício da inversão de papéis dá às mulheres uma oportunidade de corrigir os desequilíbrios sociais entre homens e mulheres em uma competição cômica aberta majoritariamente aos homens, conforme podemos perceber na parábase da peça. Ademais, em outro nível, o próprio ritual privado também inverte a direção da transgressão; agora os homens são forçados a invadir o espaço proibido e adentrarem o mundo secreto das mulheres com o propósito de espionálas e revelar seus segredos.

O discurso em que o Parente comenta a intimidade de Eurípides, sua familiaridade com os segredos das mulheres reproduz a transgressão de Eurípides do trágico decoro. Essa transgressão também é realizada de forma dramática como a própria violação do recinto sagrado reservado 
às mulheres em seu ritual. Tendo penetrado antes em um mundo em que fora proibido de entrar, Eurípides agora adentra nele novamente, só que dessa vez a infiltração se inicia com o Parente no rito das Tesmofórias. Na comédia, essas revelações da "natureza" das mulheres causam mais riso do que indignação entre os espectadores, explica Tzanetou. É no teatro trágico que os efeitos miméticos da representação operam com tal realismo e persuasão que o drama ultrapassa e invade o mundo real, enviando maridos para longe, enlouquecidos de ansiedade, para olhar para as mulheres em casa.

\section{Considerações finais}

Em vista da abordagem proposta, observamos que discutir e compreender gênero como categoria de análise nos possibilita fazer significativas reflexões sobre os papéis, normas, atitudes e comportamentos socialmente construídos e atribuídos a homens e mulheres em determinada sociedade. Desse modo, comentamos que na Atenas do século V a.C., a posição social e política de homens e mulheres exigia a participação destes na guerra e na política, em domínios de engajamento cívico, ao passo que cabia às mulheres uma existência mais marginal, definida, sobretudo, por suas obrigações como esposas e mães e em práticas religiosas. Nesse sentido, era permitida a participação feminina em festejos de natureza privada, como casamentos e ritos fúnebres, e festivais públicos religiosos sancionados pelas leis da cidade; nesses espaços delimitados, as mulheres tinham uma função político-religiosa, por assim dizer, cabendo a elas, portanto, a condução do bem-estar da comunidade.

É pertinente registrar, também, que as noções de gênero na antiguidade, sendo alicerçadas por um aparato cultural, eram baseadas no dimorfismo sexual que refletia na divisão do trabalho e nos papéis sociais de cada sexo. Assim, separava-se o masculino do feminino, amparando-se em uma estrutura de oposições binárias cujos parâmetros de demarcações de papéis eram fundados em associações simbólicas das representações dos sexos. Essa concepção grega de uma espécie de antagonismo sexual, tão evidente no culto, nos mitos e demais representações culturais, 
situa machos e fêmeas em lados adversários, conforme nos diz Zeitlin (2002, p. 86) em seu estudo sobre a representação do outro. Todas essas considerações também envolvem ideias sobre a própria sexualidade, na forma masculina ou feminina, o corpo e suas partes, como constituídos e imaginados em termos corpóreos ou não corpóreos. Em suma, gênero e sexualidade operam tanto no nível literal de referência nas relações familiares quanto no metafórico entre os espaços masculino e feminino, entre a casa e a cidade.

Em se tratando das peças de Aristófanes, discutimos que três retratam a inversão de papéis de gênero, Lisistrata, Assembleia de mulheres e Tesmoforiantes. Ao contrário da peça Assembleia de mulheres, em que personagens femininas assumem papéis masculinos, a participação das cidadãs-esposas na peça Tesmoforiantes está enraizada na realidade do festival. O objetivo dessas mulheres celebrantes das Tesmofórias não é intervir no negócio dos homens de administrar a pólis, mas sim impedir que eles se intrometam no próprio negócio delas de gerenciar o ô̂kos. As mulheres nesta comédia constroem uma realidade que é bem adequada ao palco cômico, já que colocam Eurípides em julgamento porque seus trágicos retratos de casos ilícitos de mulheres despertam suspeitas em seus maridos, atrapalhando o bom funcionamento do ôkkos.

Assim, nas Tesmoforiantes nos deparamos com o reposicionamento em torno da batalha dos sexos e do travestismo de gênero, o que compreende o domínio da estética e do visual, aspectos que se projetam no próprio domínio do teatro e dos recursos próprios da encenação. A fala das mulheres é permeada de termos relativos ao universo masculino. Desse modo, observamos no texto como elas tratam da reunião como assembleia, se autoproclamam conselho/povo das mulheres, comparamse a oradores e fazem um discurso longo e delineado retoricamente. Nesse sentido, mesmo o festival das Tesmofórias sendo mais marcadamente religioso do que político, percebemos que Aristófanes representa a celebração do festival também com fortes relações ao espaço democrático ateniense. No espaço da comédia, as mulheres atenienses não querem ser heroínas trágicas como Fedra ou Melanipa, nem compartilhar suas grandes paixões, só querem punir e silenciar Eurípides, porque suas tragédias ameaçam perturbar os arranjos domésticos das mulheres. 
A admissão exclusiva de cidadãs-esposas no festival e a eleição de magistrados oficiais nos dão mostras da rara oportunidade de vislumbrar mulheres - que de outra forma não tinham participação política na cidade - como membros de uma associação políticoreligiosa. Além disso, a obscenidade ritual marca uma reversão completa do modelo de modéstia e silêncio esperado das esposas atenienses. Ademais, a exigência de castidade e o uso de plantas anafrodisíacas sugerem uma reversão simbólica do status social das mulheres, das esposas às virgens, para promover a fertilidade. Mesmo em Lisistrata $\mathrm{e}$ Assembleia das mulheres, em que as personagens femininas assumem a liderança, é possível observar que a redefinição social das mulheres é de pouca expressividade, já que nas duas peças há o reestabelecimento e reafirmação dos papéis tradicionais das mulheres. A posição destas no oîkos e na pólis é representada positivamente. Quanto às contribuições das mulheres, suas funções de esposas e mães são representadas como valiosas dentro da performance teatral do próprio festival que celebra a fertilidade feminina e sua participação cívica.

\section{Referências}

ARISTÓFANES. Lisístrata. Tradução de Ana Maria César Pompeu. São Paulo: Hedra, 2010.

ARISTÓFANES. Tesmoforiantes. Tradução de Ana Maria César Pompeu. São Paulo: EDIPRO, 2015.

HESÍODO. Os Trabalhos e os Dias. Tradução de Mary de Camargo Neves Lafer. 3. ed. São Paulo: Iluminuras, 1996.

HESÍODO. Teogonia: a origem dos deuses. Tradução de Jaa Torrano. 3. ed. São Paulo: Iluminuras, 1995.

McCLURE, Laura. Gender and Verbal Genres. In: McCLURE, Laura. Spoken Like a Woman: Speech and Gender in Athenian Drama. Princeton: Princeton University Press, 1999. p. 32-69.

SILVA, Maria de Fátima Sousa e. A posição social da mulher na comédia de Aristófanes. Humanitas, Coimbra, n. 31/32, p. 97-114, 1979-1980. 
TZANETOU, Angeliki. Something to do with Demeter: Ritual and performance in Aristophanes' Women at the Thesmophoria. The American Journal of Philology, Baltimore, v. 123, n. 3, p. 329-367, 2002. DOI: https://doi.org/10.1353/ajp.2002.0045.

VERNANT, Jean-Pierre. As origens do pensamento grego. Tradução de Ísis da Fonseca. Rio de Janeiro: DIFEL, 2002.

VERNANT, Jean-Pierre. As origens do pensamento grego. Tradução de Ísis da Fonseca. São Paulo: Bertrand Brasil, 1989.

VERNANT, Jean-Pierre; VIDAL-NAQUET, Pierre. Mito e tragédia na Grécia Antiga. Tradução de Anna Lia de Amaral do Prado et alii. São Paulo: Duas Cidades, 1990.

ZEITLIN, Froma. Playing the Other: Theater, Theatricality, and the Feminine in Greek Drama. In: McCLURE, Laura. (ed.). Sexuality and Gender in the Classical World. Oxford: Blackwell, 2002. p. 103-143. DOI: https://doi.org/10.1002/9780470756188.ch4.

ZEITLIN, Froma. Travesties of Gender and Genre in Aristophanes' Thesmophoriazousae. Critical Inquiry, Chicago, v. 8, n. 2, p. 301-327, 1981. DOI: https://doi.org/10.1086/448156.

Recebido em: 27 de outubro de 2019. Aprovado em: 13 de dezembro de 2019. 